\title{
Predication in the syntax of hyperraising and copy raising
}

\author{
Marcel den Dikken \\ Eötvös Loránd University and Research Institute for \\ Linguistics, Hungarian Academy of Sciences \\ marcel.den.dikken@nytud.mta.hu
}

\begin{abstract}
This paper presents arguments to remove the NP-movement component from hyperraising and copy raising constructions, and to unite these constructions with an analysis in which a complex predicate is created which is predicated directly of the subject of the matrix clause. The analysis at the same time affirms the versatility of the predication relation in syntax and eliminates the need to facilitate $\mathrm{NP}$-movement of the nominative subject of a finite clause across a CP-boundary.
\end{abstract}

Keywords: predication; copy raising; hyperraising; NP-movement

\section{Introducing hyperraising and copy raising}

Hyperraising, illustrated in (1) (from Brazilian Portuguese; Ferreira 2000; 2004; Martins \& Nunes 2006; Nunes 2008), and copy raising, exemplified by (2) (from colloquial English; Potsdam \& Runner 2001; Asudeh \& Toivonen 2012), have enjoyed a good amount of attention in the context of theoretical discussions about the locality constraints on movement and the way in which chains with multiple copies of a moved constituent are resolved in the PF component. A strand of research subscribes to the view that the constructions in (1) and (2) result from movement of the surface subject from the lower clause into the higher clause, across the boundaries of a finite CP. On such an approach, in the Brazilian Portuguese hyperraising construction in (1), the copy of the moved noun phrase in the subordinate clause remains silent at PF, while in the English copy raising constructions in (2) the lower copy is reduced to a pronoun. ${ }^{1}$

${ }^{1}$ Martins and Nunes (2006) report alternations of the type in (ia,b) for Brazilian Portuguese. (ib) looks like an English-type copy raising construction, but then without the like that characterises the English construction. I note that colloquial English appears to be developing a version of (ib) (i.e., (2) without like), judging from attested examples such as (ii). (For such sentences, Ura 1998 attributes to Lasnik the observation that they deserve "???".) 
(1) o João parece que 'ta doente

the João seems.3SG that be.3SG sick

'João seems to be sick.'

(2) John seems $\{$ like/as if/as though $\}$ he's sick.

\section{Hyperraising and copy raising without raising}

As an alternative to the movement-based analysis, what I would like to propose is that the subject of the matrix clause in both (1) and (2) originates in that clause, and is introduced there as the subject of a predicate formed thanks to the fact that the matrix subject binds a pronoun in the lower clause as a bound variable. ${ }^{2}$ Schematically, the proposal is represented in (3):

(3) [RP $\operatorname{SUBJECT}_{i}[$ RELATOR $[\mathrm{CP}$ C [TP PRONOUN $\left.i \ldots] \mid]\right]$

(i) a. os meninos parecem que viajaram ontem

the boys seem.3PL that travelled.3PL yesterday

b. os meninos parecem que eles viajaram ontem

the boys seem.3PL that they travelled.3PL yesterday

both: 'the boys seem to have travelled yesterday'

(ii) a. Dad talks about retiring but he seems he's afraid he'll have nothing to do afterwards.

b. he seems he's not even trying

c. he seems he's finally ready

d. he seems he's interested

e. you seem you're always looking out for everyone you seem you're jail bait

(from Little Miss Sunshine; American film, 2006)

${ }^{2}$ That pronoun is usually the subject of the subordinate clause. But Asudeh and Toivonen (2012) point out that for a subset of English speakers (and quite generally in Swedish, too), the bound variable does not have to be the subject of the subordinate clause: for many speakers it can also be the subject of a more deeply embedded clause, as in (ib); and for some it can also be a non-subject, as in (ic). For a very small group of English speakers, it is even possible to have no copy pronoun in the lower clause at all, as shown in (id) (whose Swedish counterpart turns out to be considerably less rare).

(i) a. John seems like he defeated Mary.

b. John seems like the judges ruled that he defeated Mary.

c. John seems like Mary defeated him.

d. John seems like Mary won. 
That the pronominal subject of the subordinate clause in hyperraising and copy raising constructions is necessarily a bound variable is shown by the fact that in (4), the ellipsis can only be resolved in such a way that the subject of the elliptical embedded clause in the second conjunct is coreferent with the subject of the second conjunct - a case of obligatory sloppy identity typical of bound variable readings. (I illustrate this only for English; in Brazilian Portuguese, null subjects of finite clauses always give rise to a sloppy reading under ellipsis.)

(4) John seems $\{$ like/as if/as though $\}$ he's sick, and Sue does like siek, too.

It is precisely this bound variable that turns the non-argumental subordinate clause into a predicate for the subject of RP. Analysed in this way, hyperraising and copy raising constructions are in an important way similar to tough-movement constructions (he is tough to please), where the null operator in the infinitival clause is obligatorily bound to the subject of the tough adjective (there is only a sloppy reading available for he is tough to please and she is, too).

The analysis in (3) is very close to the account of English and Swedish copy raising constructions advanced by Asudeh and Toivonen (2012) (once their LFG-based analysis is adapted to a mainstream Chomskyan format). Asudeh and Toivonen (2012) say of like and as in the English copy raising construction in (2) that they are predicate heads. In line with my earlier work on like and as (Den Dikken 2006), I take these elements to be spellouts of the RELATOR head mediating the predication relation between the clause in their complement and the subject of the seem clause. The particle out, another natural candidate for lexicalising the RELATOR head, also figures in the copy raising construction in English:

(5) John turns out he is sick.

For all the various elements occurring between the matrix verb and the lower clause in English copy raising constructions (including the zero element in the examples mentioned in footnote 1 , (ii)), it is plausible to treat them as exponents of the RELATOR:

(6) $\left[\mathrm{seem} / \operatorname{turn}\left[\mathrm{RP} \mathrm{John}_{i}\left[\mathrm{RELATOR}=\{\right.\right.\right.$ like, as, out, $\emptyset\}\left[\mathrm{CP}\right.$ (if/though) he ${ }_{i}$ is sick] $\left.\left.]\right]\right]$

The primary role of like and its ilk is not to create a predicate but to mediate the predication relationship involved in copy raising constructions. 


\section{NPIs and idiom-chunk subjects in hyperraising and copy raising}

\subsection{NPI-licensing}

In the Brazilian Portuguese hyperraising construction, the idiomatic NPI mexer um dedo 'move a finger' is grammatical in the embedded clause when ninguém 'nobody' serves as the subject of the matrix clause, as shown in

(7) (from Nunes 2008):

(7) ninguém parecia que ia mexer um dedo para me ajudar nobody seemed that went move a finger for me help 'nobody seemed like they were going to lift a finger to help me'

The grammaticality of (7) is remarkable because the NPI-idiom mexer um dedo is a very strict NPI: it cannot be licensed long-distance even in Neg-raising contexts: ${ }^{3}$

(8) *ninguém acha que o João vai mexer um dedo para me ajudar nobody thinks that João goes lift a finger to me help

The contrast between (7) and (8) has generally been taken to argue for a movement analysis of hyperraising constructions (see Nunes 2008, for instance). Convergent with such an approach is the fact (not previously noted, to my knowledge) that when the negative element in the matrix clause is the particle não 'not', the hyperraising and 'think' examples are both bad: ${ }^{4}$

${ }^{3}$ I have come across one speaker who finds (8) acceptable (while still frowning on (10), below); my other informants firmly reject it. This speaker also differs from the others with regard to $(7) \sim(9)$, for which this speaker reports no significant contrast. Notice that even for this informant, hyperraising constructions are different from Neg-raising environments with 'think'-type verbs. The text judgements for (7)-(10) reflect those reported by my other informants, where "?*" indicates that the exact status of $(9)$ is somewhat variable but it is consistently found to be worse than (7).

${ }^{4}$ In the context of NPI-licensing, English copy raising constructions are not in play because it is impossible to construct examples with diagnostic power similar to that of the Brazilian Portuguese cases. Strict NPIs such as lift a finger and until-clauses combined with punctual predicates are licensed in the clause embedded under negated seem, even when this clause is the associate of the 'expletive' $i t$ :

(i) a. doesn't seem/look like he will lift a finger to help me

b. it doesn't seem/look like they found the problem until it was too late

So the fact that there is no contrast in copy raising between (iia) and (iib) (both being acceptable) is not particularly revealing. Such examples serve neither to support nor to undermine an analysis of copy raising in terms of predication. 
(9) ${ }^{2 *}$ o João não parecia que ia mexer um dedo para me ajudar João not seemed that went move a finger for me help

(10) *eu não acho que o João vai mexer um dedo para me ajudar I not think that João goes lift a finger to me help

For the movement account of Brazilian Portuguese hyperraising constructions, the difference between (7) and (9) falls out from the assumption that ninguém starts out in the subordinate clause, in a position local to mexer um dedo, and licenses the NPI prior to raising. On the alternative complex predicate formation analysis, the NPI in (7) is licensed thanks to being included in the predicates created by the bound variable dependency in (3). Again, only examples in which the intended matrix licenser of the NPI in the embedded clause is the subject of predication for the complex predicate are predicted to be grammatical, just as on the movement analysis. So for now, the two analyses are in a tie - but see $\S 5.3 .3$ for a possible tie-breaker.

\subsection{Idiom chunks as subjects}

Martins and Nunes (2006) draw attention to another interesting property of the hyperraising construction in Brazilian Portuguese: the fact that it allows an idiom chunk belonging to the embedded predicate to be licensed as the subject of the matrix verb, as in (11):

(11) o pau parece que comeu feio

the stick seems that ate ugly

'it seems that there was a big discussion/fight'

For Martins and Nunes, the grammaticality of such examples furnishes an argument for an analysis of hyperraising in terms of A-movement rather than some form of $\bar{A}$-movement. But there is an alternative to treating (11) in terms of actual raising: o pau in (11) can be base-generated directly as the subject of que comeu feio, as shown in (12), modelled on (3).

(12) [RP o pau $i$ [RELAToR [CP que [TP pro $\left.\left.\left.\left._{i} \ldots\right]\right]\right]\right]$

That idiom chunks can serve as subjects of predication to predicates containing a bound variable linked to the idiom chunk is evident from the fact

(i) a. nobody seems/looks like they found the problem until it was too late

b. they don't seem/look like they found the problem until it was too late 
that tough-movement (the textbook example of predicate-creating null operator movement) shows 'idiom connectivity' for all but the most rigid of idioms (notwithstanding occasional claims to the contrary in the literature):

(13) a. advantage is easy to take of her

b. headway is easy to make on this project

c. homage is easy to pay to her

d. tabs are easy to keep on him

e. * the bucket is easy to kick

The fact that (13e) fails fits in with the fact that the idiom kick the bucket is frozen in every syntactic way: its only variability lies in the tense of the verb; it is not manipulable in any other respect. But take advantage, make headway, pay homage and keep tabs are grammatical in the tough-movement construction. What this means is that the object of these idioms can be related to the verb through predication: in the tough-movement construction, the AP containing the infinitival clause serves as a predicate of the subject of the tough-clause:

(14) [RP advantage $i$ [RELATOR [AP tough [CP $O p_{i}$ [TP PRO to take $t_{i}$ of her]]I]]

Null operator movement and predication are the basic ingredients of the standard approach to tough-movement constructions in the generative literature. With the idiom chunk licensed under predication in $(14),{ }^{5}$ we can build a natural bridge to the Brazilian Portuguese hyperraising case in (11), treatable along the lines of (12). No appeal to A-movement is necessary or helpful here, just as there can be no appeal to A-movement in the examples in (13).

The above discussion leads us to expect idiom chunks to feature in the English copy raising construction as well - which is indeed the case, as Potsdam and Runner $(2001,3)$ and Asudeh and Toivonen (2012) note: ${ }^{6}$

${ }^{5}$ And also in cases such as (ia), which is remarkable for the fact that only exists as an idiom in a form in which a portion of the idiom (leg) is the subject of a predicate (the infinitival relative clause to stand on) created via empty operator movement: (ia) has an idiomatic reading ('your case entirely lacks support') but (ib) does not.

(i) a. you don't have a leg to stand on

b. you don't stand on a leg

${ }^{6}$ There appears to be some variation in the judgements for the examples in (15), judging from Potsdam \& Runner (2001) and Asudeh \& Toivonen (2012). Potsdam 
(15) a. the cat seems like it is out of the bag

b. the shit seems/looks like it could hit the fan any moment now

c. advantage seems like it was taken of the workers

\section{On the distribution of hyperraising and copy raising}

\subsection{No hyperraising or copy raising out of clausal internal arguments}

In analyses of hyperraising and copy raising constructions that take these labels literally, the clause in which the matrix subject originates (and from which it raises) is the internal argument of the matrix predicate head. Some of the proponents of a movement approach to copy raising and hyperraising (Nunes, in particular) are also on record as advocating a movement analysis of (obligatory) control, where once again the subordinate clause is often a complement. If (16a) has a movement derivation, a question that then arises is why (16b) is not a copy raising construction - that it is not can be deduced, for instance, from the fact that the elliptical second conjunct in (16b) does not force a sloppy identity reading (unlike (16a)), and that (16c), with different subjects in the two clauses, is grammatical (unlike a seem like-type copy raising construction).

(16) a. he would prefer not to be asked about details, and so would she

b. he would prefer that he not be asked about details, and so would she

c. he would prefer that she not be asked about details

On the predicational approach to copy raising and hyperraising constructions, the fact that (16b) does not behave like such constructions is easy to understand: the clause embedded under prefer is its internal argument, receiving a $\theta$-role from its selector; constituents serving as arguments cannot be predicates, so it is impossible to interpret the subordinate clause in (16b) as a predicate of the matrix subject. The predicational approach

and Runner (2001) also point out that "expletive" there occurs as the subject of "copy raising" constructions:

(i) there seems like there is going to be a riot

On standard Chomskyan assumptions regarding there-existentials, this would serve as a powerful argument for a movement analysis. But there is good reason to believe that there is not in fact an expletive (see, i.a., Williams 1994; 2006; Moro 1997; Hoekstra \& Mulder 1990). For present purposes, a Williams-style approach to there, treating it as a subject of predication, would be particularly efficacious. 
directly guarantees, therefore, that clauses that serve as arguments are not eligible for copy raising or hyperraising. The movement approach, by contrast, would expect complement clauses to be eminently suitable for launching copy raising and hyperraising - especially when coupled with a movement theory of control (Boeckx et al. 2010).

\subsection{No copy raising in relative clauses}

Unlike the complement clauses in (16), relative clauses do serve as predicates. The predicational approach to hyperraising and copy raising might thus lead one to expect that examples of the type in (17) should be grammatical, contrary to fact. If the predicational approach is on target, then why are $(17 \mathrm{a}, \mathrm{b})$ ungrammatical?

(17) a. *[a student like he is distracted] will fail the exam

b. *[a student like his mind is somewhere else] will fail the exam

On the approach to copy raising presented in section 2, the structure of the examples in (17) would look as in (18).

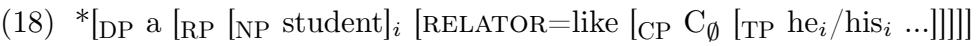

The RP subportion of the structure in (18) is ill-formed due to predication failure. The RELATOR like needs to link the NP in its specifier (the subject) to some predicate. But the $\mathrm{CP}$ in the complement of the RELATOR fails to qualify as a predicate because CPs are not inherently predicative and the $\mathrm{CP}$ in (18) cannot be a derived predicate either as the pronoun inside $\mathrm{CP}$ is not construable as a bound variable. That he/his cannot be so construed is due to the fact that the head of the relativised noun phrase (NP in SpecRP) is smaller than DP, and therefore not a possible binder for the bound-variable pronoun. Coreference between the pronoun inside $\mathrm{CP}$ and the relativised DP as a whole, apart from creating an " $i$-within- $i$ " effect, will not deliver a predicate for the head of the relativised noun phrase either. So the RP subportion of the structure in (18) is ill-formed because like fails to relate NP qua subject to a predicate.

\subsection{Hyperraising or copy raising in plain copular sentences?}

We have seen that 'semi-copulas' such as English seem and Brazilian Portuguese parecer 'seem' participate in syntactic structures in which a finite 
$\mathrm{CP}$ is construed as a predicate thanks to the prominent presence inside it of a bound variable pronoun coindexed with the matrix subject. We might now expect that such predicative construal of a finite $\mathrm{CP}$ containing a bound variable pronoun should also be licit in plain copular sentences. But examples of the type in (19) are ungrammatical. Why?

(19) a. *he is (that) he is distracted

b. *he is (that) his mind is somewhere else

A natural answer suggests itself when we consider the structure that such sentences would be expected to have:

(20) $*{ }_{\text {RP }}$ he $_{i}$ [RELATOR=is [CP (that) [TP he $i$ is distracted / his $i$ mind is somewhere else]]]]

This structure is rejected because the portion of the structure outside $\mathrm{CP}$ adds nothing to the contents of the CP. In seem like copy raising constructions, the RELATOR head of the matrix predication structure is filled with something meaningful (like) and there is something meaningful in the matrix clause (seem). Both of these ingredients make the matrix predication non-equivalent to the lower one. But in the copular sentences in (20), there is nothing that could contribute upstairs to the semantics of the sentence above and beyond what is already contributed by the embedded $\mathrm{CP}$ : he is distracted and his mind is somewhere else say all there is to say.

If this is on the right track, we expect that when we place like or as in the RELATOR position and merge RP with the plain copula, the result will be grammatical. And indeed, sentences of the type in (21) and (22) occur:

(21) a. he's like he's distracted

b. he's like his mind is somewhere else

(22) a. he's as if he's distracted

b. he's as if his mind is somewhere else

Of course like also occurs as lexical predicate heads (what's he like?, he's just like me). But in strings of the type he's like he... (and she's like she..., etc.), like can only be the RELATOR of a predication relation between the matrix subject and the clause that follows it. The mere fact that like and as have some meaningful content seems to suffice to render (23) grammatical.

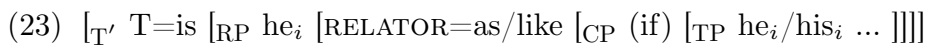




\subsection{No hyperraising with inflected infinitives}

In the discussion of hyperraising constructions in Brazilian Portuguese, I displayed examples in which the subordinate clause (i.e., the predicate of the matrix subject, on the analysis advocated here) is finite. Brazilian Portuguese also has inflected infinitives, and such inflected infinitives can combine with the kinds of matrix elements that could be expected to support hyperraising derivations. But although (24a) is grammatical, its hyperraising counterpart in (24b) is entirely impossible.
(24) a. è bem provável [os professores terem
elogiado o diretor]
is very probable the professors have.INF.3PL praised the director 'it is very likely for the professors to have praised the director'
b. * os professores são bem prováveis[terem elogiado o diretor] the professors are very probable have.INF.3PL praised the director intended: 'the professors are very likely to have praised the director'

The null hypothesis regarding the structure of the inflected infinitives of Portuguese is that they are IPs: unlike finite clauses, the infinitive in (24) does not combine with anything that could be mapped into the C-position. Absent any concrete evidence for a CP layer, the grammar proceeds on the presumption that the infinitival clause in (24) is no larger than IP. If it is correct that we are dealing here with an IP, the ill-formedness of (24b) falls out immediately from the predicational approach: the bound variable pronoun needed inside the inflected infinitive in this hyperraising attempt would, by being coindexed with the matrix nominative subject, be bound within its local domain, in violation of Principle B of the Binding Theory.

There is an indication that the approach to (24b) presented in the previous paragraph is on the right track. As Nunes (2008) points out, while (24b) is indeed unsalvageable, there are matrix adjectives selecting inflected infinitives for which a grammatical hyperraising outcome can be created. Consider the examples in $(25):^{7}$
(25) a. è fácil/difícil (de)[os professores elogiarem os alunos] is easy/difficult of the professors praise.INF.3PL the students 'it is easy/hard for the professors to praise the students'

\footnotetext{
${ }^{7}$ In the output for (25a) with de included, contraction of de and os results in dos. I abstract away from this, for representational perspicuity.
} 
b. os professores são fáceis/difíceis * (de) [elogiarem os alunos] the professors are easy/difficult of praise.INF.3PL the students 'the professors often/rarely praise the students'

Hyperraising of os professores 'the professors' out of the inflected infinitive is possible here - but only if $d e$ is present. If we follow widely adopted assumptions regarding the status of de in infinitival clauses in the Romance languages (cf. Kayne 1975 on French de, for instance), de in (25) is an exponent of the C-head of the inflected infinitive. The descriptive generalisation that then emerges is that hyperraising is possible in inflected infinitive constructions ONLY when the infinitival clause is as large as a $\mathrm{CP}:(25 \mathrm{~b})$ is ungrammatical without $d e$.

On the approach to hyperraising constructions laid out in section 2 , this distribution of de is immediately expected. In (24b) and in (25b) without $d e$, the infinitival clause is no larger than IP, which causes the bound variable pronoun present in the structure of these sentences to be locally bound, in violation of Principle B. What makes (25b) WITH de different is precisely the fact that here, the CP layer delineates the local domain for the pronoun in the subject position of the infinitive: the pronoun is now free in its local domain, and welcome to be coindexed with the matrix subject. It is this coindexation that turns the embedded infinitival clause into a predicate for the subject; without coindexation, there would be predication failure, yielding a violation of the Principle of Full Interpretation.

The way that I have characterised it, the pattern in (25) would be profoundly difficult to make sense of on an analysis of hyperraising that takes the label literally: raising (i.e., NP-movement) would be expected to be harder across a CP than across a mere IP, definitely not easier. Nunes (2008), who advocates a movement analysis, presents an entirely different take on the facts in (25). For him, de, when present, is the assigner of inherent case to the infinitive; and when the infinitive has inherent case (and only then), it does not block movement of its subject into the matrix clause. The way in which inherent case is mobilised in this analysis in order to make NP-movement possible is technically feasible. But the hypothesis that $d e / d i$ in Romance is an inherent case assigner, while perhaps defensible for its spatial uses ('he flew in from Paris'), seems hard to maintain for the full gamut of occurrences of this prepositional element - esp. for the $d e / d i$ found in qualitative binominal noun phrases such as (26) (discussed in Den Dikken 2006), or the de/di in expressions such as 'today's/yesterday's newspaper' (see Portuguese (27)). 
(26) a. cet idiot de médecin

that idiot of doctor

b. quell' ignorante di dottore

that ignoramus of doctor

'that idiot/ignoramus of a doctor'

(27) o diário de hoje/ontem

the newspaper of today/yesterday

It is nonsensical to treat the $d e$ of (25) as a spatial preposition (meaning 'from'). But if it is not spatial 'from' that we are dealing with in (25), it is unlikely that it is an inherent case assigner. If de in (25) is not an inherent case assigner, a case-based account of the distribution of de in (25) is unavailable. ${ }^{8}$

In summary, on the predicational approach to hyperraising, (24b) and de-less (25b) are ill-formed because (a) the silent pronominal subject of

${ }^{8}$ There are other things that Nunes (2008) derives from his hypothesis that $d e$ in (25) is an inherent case assigner - most notably, the fact that a de-marked inflected infinitive, unlike a de-less one, cannot be placed in the structural subject position of a higher clause: (i). This is an interesting and important observation, which does indeed fall out directly from Nunes' hypothesis. But the alternative approach to de espoused in the main text can account for it, too: the 'bare' inflected infinitive (probably in virtue of its inflection) has the distribution of a nominal expression, hence can serve as a subject; a CP headed by de is not nominal, and therefore (given that, as a rule, only nominal constituents can satisfy the 'EPP') cannot be positioned in the structural subject position of a finite clause.

(i) $\left[\left({ }^{*} \mathrm{~d}\right)\right.$ esses professores elogiarem alguém] é difícil of.these professors praise.INF.3PL someone is difficult 'for these professors to praise someone is difficult'

From a comparative perspective, it is worth pointing out that a contrast similar to the one in (i) is found with (systematically uninflected) te-infinitives in Dutch: (ii). Note that it is entirely standard in the literature on Dutch infinitival constructions to treat $o m$ as an infinitival complementiser. An analysis of the $o m$ in (ii) as an inherent case assigner, while historically sensible, would be synchronically quite unorthodox. The fact that the distributions of $d e$ and $o m$ in (i) and (ii) seem to be perfectly matched, in conjunction with the infeasibility of an inherent case approach to om and the standard treatment of this element as a complementiser, suggests that the position of de in (i) is C. That CPs tend to resist the structural subject position of a finite clause is well known since at least Koster (1978).

(ii) $\left[\left({ }^{*} \mathrm{om}\right)\right.$ je verlies te moeten toegeven $]$ is nooit leuk COMP your defeat to have.to admit is never nice 'to have to admit your defeat is never nice' 
the inflected infinitive must be coindexed with the matrix subject in order for the latter to be supplied with its requisite predicate, but (b) such coindexation contravenes Principle B of the Binding Theory due to the fact that the pronoun and its binder are in the same local domain. The insertion of $d e=\mathrm{C}$ in $(25 \mathrm{~b})$ circumvents this problem, with $\mathrm{CP}$ now shielding the pronoun inside the inflected infinitive from its antecedent.

\section{Hyperraising in Hungarian: first explorations}

At this point, I would like to bring into this discussion of hyperraising two Hungarian constructions not hitherto subjected to detailed scrutiny in the literature (É. Kiss 2009 looks briefly at constructions of the type illustrated in (28) but does not study their syntax in detail) that look like potential candidates for involving NP-movement out of an embedded finite clause:

(28) a. a fénymásoló el kell, hogy túnjön

the copier(NOM) dis- needs that appear.SBJ.3SG

'the photocopier needs to disappear'

b. a fénymásoló ki kell, hogy kapcsolva legyen

the copier(NOM) off needs that switched be.SBJ.3SG

'the photocopier needs to be switched off'

(29) a. a fénymásoló biztos/valószínú, hogy el fog tûnni

the copier(NOM) certain/likely that dis- will.3SG appear.INF

'the photocopier is certain/likely to disappear'

b. a fénymásoló biztos/valószínú, hogy kikapcsolva lesz

the copier(NOM) certain/likely that off.switched will.be.3sG

'the photocopier is certain/likely to be switched off'

In both (28) and (29), the nominative Theme argument of the embedded unaccusative verb eltún 'disappear' or the passive participle kikapcsolva 'switched off' shows up not in the hogy 'that' clause but in the matrix clause, featuring kell 'need' or the adjectives biztos 'certain' or valószinú 'likely' as its predicate head. It is highly implausible to take a fénymásoló 'the copier' to receive a $\theta$-role from kell 'need', biztos 'certain' or valószinú 'likely': we cannot sensibly attribute an obligation, certainty or likelihood 
to the referent of this noun phrase. ${ }^{9}$ It seems a priori reasonable to think that we are dealing here with examples of hyperraising. ${ }^{10}$

\subsection{A or $\bar{A}$ ?}

As they stand, the sentences in (28) and (29) are susceptible in principle of two alternative syntactic parses: a fénymásoló 'the copier' could be located in the structural subject position of the matrix clause; but because of the placement of the nominative noun phrase in initial position in the matrix clause, it is also possible to treat these examples in terms of long-distance topicalisation of the subject of the lower clause straight into an $\bar{A}$-position in the left periphery of the higher clause. If the latter is the way in which the sentences in (28) and (29) are derived, they obviously do not bear on the syntax of hyperraising: the matrix nominative is in an $\bar{A}$-position; the matrix clause is an impersonal construction with a silent expletive subject (cf. English the photocopier, it is important/likely that they deliver on Friday).

There are a number of ways in which we can manipulate our initial examples in (28) and (29) to examine whether they involve long-distance topicalisation of the subject of the embedded clause or instead feature the

${ }^{9}$ It was primarily for this reason that I chose unaccusative and passive constructions in my examples in (28) and (29), with surface subjects whose $\theta$-roles are not compatible with the matrix predicates. For a bevándorlók el kell, hogy túnjenek 'the immigrants need to disappear', it is less immediately clear that the matrix subject is not an argument of kell: unlike the photocopier in (28), the immigrants can readily be construed as the obligation holders.

I note for completeness' sake that É. Kiss $(2009,223)$ observes that the modal $s z-$ abad 'may, be allowed' also participates in constructions of the type in (28). I have found examples with muszáj 'must' as well.

${ }^{10}$ For nehézségek biztos nem lesznek 'difficulties certain not will.be, i.e., it is certain that there will not be difficulties', one could perhaps easily assume that biztos is an adjective with an adverbial distribution (essentially biztosan without the adverbialising suffix -an). But for (29), which contains the complementiser hogy, such a strategy makes no sense: biztos, hogy cannot be treated as an adverbial element because it is not a constituent (pace É. Kiss's 2009, 224 treatment of kell, hogy as a constituent; see footnote 20, below); and adverbial biztos(an) cannot be the main predicate of a clause. Interestingly, variants of (29) with unambiguously adverbial biztosan 'certainly' and valószinúleg 'likely (ADV), probably' and retention of hogy are spreading in present-day Hungarian. I am inclined to treat these as cases of hypercorrection. I have no proposal to make for their syntax at this time. But for the examples in (29), the conclusion seems inescapable that we have to treat biztos/valószinú as a matrix adjective that has the hogy-clause in its complement, very much like kell in (28). 
nominative in an A-position in the matrix clause. I will go over these in the following subsections.

\subsubsection{Linear order}

In (30) and (31), the nominative is placed in clause-internal position rather than, as in (28) and (29), in the left periphery of the matrix clause:

(30) a. ?AZÉRT kell a fénymásoló, hogy eltúnjön, mert... therefore needs the copier(NOM) that disappear.SBJ.3sG because 'the photocopier needs to disappear because...'

b. ?AZÉRT kell a fénymásoló, hogy kikapcsolva legyen, mert... therefore needs the copier(NOM) that off.switched be.SBJ.3sG because 'the photocopier need to be switched off because...'

(31) a. ?AZÉRT valószínú a fénymásoló, hogy el fog tưnni, mert... therefore likely the copier(NOM) that dis- will appear.INF because 'the photocopier is likely to disappear because...'

b. 'AZÉRT valószínú a fénymásoló, hogy kikapcsolva lesz, mert... therefore likely the copier(NOM) that off.switched will.be because 'the photocopier is likely to be switched off because...'

In these sentences, azért 'therefore' is placed in the focus position of the matrix clause, immediately followed by the predicate head. The nominative here cannot be in the left periphery of the matrix clause; it is the occupant of a clause-internal A-position instead. The judgements on placing a fénymásoló in clause-internal position in the matrix are variable; ${ }^{11}$ but there are speakers for whom the sentences in (30)-(31), while somewhat marginal, are grammatical.

${ }^{11}$ Quite in general, it is difficult, in the constructions under discussion, to separate the matrix predicate head from the hogy that introduces the subordinate clause; see also footnote 20, below. Further research will be necessary to determine why, for speakers who accept (30), examples of the type in (i) (with csak akkor 'only then' as the focus) and (ii) (with nem 'not') are apparently so much worse than (30).

(i) *csak AKKOR kell a fénymásoló, hogy eltünjön, ha/amikor... only then needs the copiers that disappear.SBJ.3SG if/when 'only then does the photocopier need to disappear if/when...'

(ii) *nem kell a fénymásoló, hogy eltûnjön not needs the copier that disappear.SBJ.3SG 'the photocopier does not need to disappear' 


\subsubsection{Small clausal ECM complements to epistemic verbs}

For constructions with adjectival predicate heads, a particularly convenient way to guarantee that their subject is in a clause-internal A-position rather than in an $\overline{\mathrm{A}}$-position in the left periphery is to place the adjectival predication in the ECM complement of an epistemic verb such as tart 'take, consider', and to ensure (again, with the help of focus syntax) that tart and the adjective 'embrace' the subject of predication. For the case of (29a) with valószinú 'likely', I have done this in (33). The modal kell cannot be embedded under tart; but the adjective fontos 'important' is semantically close enough to kell to stand in for it, as in (32).

(?) AZÉRT tartom a fénymásolót fontosnak, hogy eltúnjön therefore take.1SG the copier.ACC important that disappear.SBJ.3SG 'therefore I consider it important that the photocopier disappear'

(?) AZÉRT tartom a fénymásolót valószínúnek, hogy el fog túnni
therefore take.1SG the copier.ACC likely that dis- will appear.INF
'therefore I consider it likely that the photocopier will disappear'

The outputs in (32) and (33) are somewhat marginal, but generally considered to be grammatical.

\subsubsection{Agreement with the matrix predicate head}

In (28) and (29), the fact that the nominative is third person singular makes it impossible to verify whether it controls $\varphi$-feature agreement with the matrix predicate head, kell or biztos/valószinú. The examples below feature plural a fénymásolók, which, when serving as the structural subject of the matrix clause, is expected to trigger plural number inflection on the predicate head. Hungarian inflects both finite verbs and adjectives for the number specification of their subjects; so this diagnostic can be exploited for both kell and the examples featuring adjectives.

Let me start by showing what happens when the nominative is in sentence-initial position in the matrix clause, as in our ogininal examples in (28) and (29). Here, when plural a fénymásolók (whose final $-k$ is the plural marker) replaces the singular, we still see only singular inflection on the predicate head: plural agreement is quite impossible in (34) and (35).

(34) a fénymásolók el kell/*kellenek, hogy túnjenek

the copiers(NOM) dis- needs/need.3PL that appear.SBJ.3PL

'the photocopiers need to disappear' 
(35) a fénymásolók valószínü/*valószínúek, hogy el fognak túnni the copiers(NOM) likely/likely.3PL that dis- will.3PL appear.INF 'the photocopiers are likely to disappear'

This is consistent with these examples featuring long-distance topicalisation of the nominative subject of the embedded clause straight into a position in the matrix $\overline{\mathrm{A}}$ left periphery.

When the notional subject of the embedded clause appears instead in a clause-internal position in the matrix, it cannot be in a topic position in the $\bar{A}$-portion of the structure. Since Hungarian finite verbs and adjectives generally must agree in $\varphi$-features with their subjects, we expect that in the constructions illustrated in (30)-(33), there must be plural inflection on kell or the adjective when plural a fénymásolók is substituted for singular a fénymásoló. For the adjectival examples, this expectation is entirely fulfilled: (36) (for those speakers who accept (31)) and (37) are grammatical only with plural marking on the adjective.

(36) ?AZÉRT valószínư*(ek) a fénymásolók, hogy el fognak tûnni therefore likely*(PL) the copiers(NOM) that dis- will.3PL appear.INF 'therefore the photocopiers are likely to disappear'

(37) a. ${ }^{(?)}$ AZÉRT tartom a fénymásolókat fontos*(ak)nak, hogy eltúnjenek therefore take.1SG the copier.PL.ACC important*(PL)DAT that disappear.SBJ.3PL 'therefore I consider it important that the photocopier disappear'

b. (?) AzÉRT tartom a fénymásolókat valószínư*(ek)nek, hogy el fognak túnni therefore take.1SG the copier.PL.ACC likely*(PL)DAT that dis- will appear

Interestingly, however, the modal kell will not inflect for the number of the clausemate nominative even when this noun phrase appears in clauseinternal position:

(38) 'AZÉRT kell/*kellenek a fénymásolók, hogy eltúnjenek therefore needs/need.3PL the copiers.PL(NOM) that disappear.SBJ.3PL

'therefore the photocopiers need to disappear'

So despite arguably being the structural subject of the kell-clause, the nominative plural in (38) does not engage in a $\varphi$-feature agreement relation with the matrix predicate head. This is especially striking in view of the fact that this modal does in fact have a third person plural form in its paradigm. We see kellenek surfacing in (39), which is very similar to (38) but does not involve promotion of the nominative subject of the lower clause into the higher clause: the subjects of the two clauses have different 
$\varphi$-features here. In (39), the hogy-clause is a purpose ('so that') or rationale ('in order to') clause in an adjunction position, not the complement of the modal kell; the plural subject of the matrix clause is an argument of kell here ('these machines are needed').

$$
\begin{aligned}
& \text { AZÉRT kellenek ezek a gépek, hogy megoldjuk a problémainkat } \\
& \text { therefore need.3PL these machines that PV.solve.SBJ.1PL our problems.ACC }
\end{aligned}
$$
'we need these machines so/in order that we can solve our problems'

The fact that the modal kell in (38) is not, and cannot be, inflected for the $\varphi$-features of the nominative, unlike what we see in the hyperraising and copy raising constructions in (1) and (2), introduces a complication that our syntactic analysis should be able to explain. I will return to the matter in section 5.3.6.

\subsubsection{Summary: $A$ or $\bar{A}$ ?}

In the previous subsections, we have seen reasons to believe that the nominative in the matrix clause typically finds itself in the $\bar{A}$ left periphery when it appears in sentence-initial position (as in our initial examples in (28) and (29)) but that it must occupy an A-position in that clause when it occurs in clause-internal position (as in (30)-(33)). In the case of adjectival predicates, the matrix noun phrase can be marked with accusative case and control definiteness agreement on the matrix verb, and trigger $\varphi$-feature inflection on the predicate head, as shown in (32) and (33). The case of the modal kell 'need' deserves special attention: although the nominative can occur clause-internally here as well, kell resists $\varphi$-agreement with it (as illustrated in (38)).

All things considered, it seems to me clear that there is a proper basis for thinking that with kell 'need' (and also with szabad 'may', muszáj 'must'; see footnote 9) and adjectives like valószinu 'likely', Hungarian has a syntactic construction that resembles the hyperraising and copy raising constructions in (1) and (2) in important ways. In what follows, I will explore the parallels between the Hungarian cases and the more familiar hyperraising and copy raising constructions from Brazilian Portuguese and English in greater depth, and I will also present an explanation for the agreement facts seen with kell. I will start my discussion of the Hungarian facts with the adjectival cases, for which I can be brief. 


\subsection{The adjectival cases}

I propose an account for Hungarian hyperraising constructions with adjectives like valószinu 'likely' that follows in the footsteps of the analysis of hyperraising proposed in section 2 :

(40) [aP likely [RP SUBJect $i$ [Relator [CP C [TP PRONOUn $\left.\left.\left.\left.\left._{i} \ldots\right]\right]\right]\right]\right]$

The matrix adjective takes as its complement a small clause whose predicate is a CP with a bound-variable pronoun linked to the subject of predication. In standing outside the predication relation itself, the adjective in the Hungarian construction at hand is similar to the "semi-copula" in English copy raising constructions, whose structure is reproduced in (41) (a dressed-down version of (6), above).

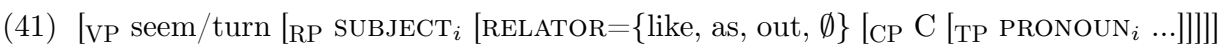

The adjective in (40) should be able to engage in an Agree relation with the subject of RP for $\varphi$-features, and in the transitive ECM constructions in section 5.1.2, the 'consider'-type verb should have the capacity to check accusative case and definiteness against the subject of RP. And indeed, as we have seen, all these things are possible in hyperraising constructions with adjectives in Hungarian, when the subject of predication appears in clause-internal position in the matrix. ${ }^{12}$

12 The adjective is the head of an 'ordinary' AP, and should therefore be eligible for modification in the familiar way. As one of the reviewers of this paper has pointed out, the adjective in (29) can indeed be intensified and accepts the comparative, as shown in (i). I have found, however, that judgements are much less positive on cases in which the subject of predication appears in clause-internal position, for reasons that need to be explored further.

(i) a. a fénymásoló teljesen biztos, hogy el fog túnni the copier(NOM) completely certain that dis- will.3SG appear.INF 'the photocopier is completely certain to disappear'

b. a fénymásoló egyre valószínúbb, hogy el fog túnni the copier(NOM) increasingly likely.CPR that dis- will.3SG appear.INF 'the photocopier is increasingly likely to disappear' 


\subsection{The modal cases}

\subsubsection{Some background on kell constructions}

The modal kell 'need' combines with a proposition, with can be a finite hogy-clause in the subjunctive. This hogy-clause can be heralded by the proleptic pronoun $a z$, as in (42), in which case the subject of the subjunctival clause usually remains inside that clause. ${ }^{13}$

(42) az kell, hogy Pali elmenjen

it needs that Pali PV.go.SBJ.3SG

'it is necessary for Pali to go away' az nem kell, hogy Pali elmenjen

it not needs that Pali PV.go.SBJ.3SG

'it is not necessary for Pali to go away'

Alternatively, the subject of elmenjen 'go away' can be realised in the kellclause, as in (43a), with nominative Pali, or as in (43b), with a nominative proleptic pronoun $a z$ and dative Palinak. ${ }^{14}$

(43) a. Pali el kell, hogy menjen Pali PV needs that go.SBJ.3SG

b. Palinak az kell, hogy elmenjen P.DAT it needs that PV.go.SBJ.3SG 'Pali needs to go away'
Pali nem kell, hogy elmenjen

Pali not needs that PV.go.SBJ.3SG

Palinak nem az kell, hogy elmenjen

P.DAT not it needs that PV.go.SBJ.3SG 'Pali doesn't need to go away'

The dative pattern in the b-examples in (43) is restricted in a way that suggests that this dative phrase is base-generated in the matrix clause, and harbours what I call the 'obligation holder' for the modal kell 'need'. In (43b), it is perfectly sensible for the speaker to attribute to Pali the obligation to leave. But inanimates cannot be given the obligation to do

${ }^{13}$ For a reviewer, long-distance topicalisation of Pali in (42) is possible, with focus on the proleptic pronoun:

(i) Pali, (még) Az kell, hogy elmenjen

Pali still it needs that PV.go.SBJ.3SG

14 The reader will notice a difference between the left-hand example in (43a) and its negated counterpart on the right, with respect to the placement of the preverb ("PV") el 'away'. What we see in (43a) is a kind of behaviour typical of the so-called 'stress avoiding verbs' of Hungarian, a class to which kell belongs: some stress-bearing element must be placed to the immediate left of kell. In the right-hand examples, this stress-bearing element is nem, the negation particle. In the absence of nem, some stressed element from the subordinate clause must be placed before kell, which triggers the "climbing" of the preverb of elmenjen up into the matrix clause in the left-hand examples in (43). The syntax of "preverb climbing" is not relevant to the discussion in this paper. I will set it aside entirely. 
something: they cannot serve as obligation holders. In light of this, it is not surprising that (44) is unacceptable: the embedded predicate is unaccusative and has an inanimate Theme argument to which no obligation can be attributed. ${ }^{15}$

$(44)^{? *}$ a fénymásolóknak (nem) az kell, hogy eltúnjenek

the copiers.DAT not it needs that disappear.SBJ.3PL

So for the dative pattern in $(43 \mathrm{~b})$, we now know with reasonable certainty that the dative originates in the matrix clause. In the example in (43b), this dative binds a silent pronoun in the subject position of the subordinate clause. But since the dative is licensed independently by the matrix modal kell, nothing in the grammar should require that this dative be coindexed with the subject (or any argument, for that matter) of the lower clause. And indeed, it is perfectly possible for the subject of the embedded finite clause to be disjoint in reference from the dative licensed by kell in the matrix clause, as in (45). ${ }^{16}$

(45) Palinak az kell, hogy elmenjél

P.DAT it needs that PV.go.2SG.SBJ

'Pali needs you to go away'
Palinak nem kell, hogy elmenjél

P.DAT not needs that PV.go.2SG.SBJ

'Pali doesn't need you to go away'

${ }^{15}$ To the extent that (44) gives some speakers the impression of being perhaps marginally acceptable, it is plausible to assume that this is an effect of analogy. There is, after all, a construction quite similar to (44) in which kell happily occurs with an inanimate dative, and in which it takes an inflected infinitival (rather than finite subjunctival) complement, as in (i), where the dative is the subject of the infinitive, licensed as such by the person and number inflection attached to the infinitive (see Tóth 2000 for discussion of the syntax of inflected infinitives in Hungarian). Since eltünniük is perfectly happy with an inanimate subject, and since its inflection can license the dative, there is no trouble with (i). But in (43b) and (44), where the embedded clause is finite and unable to license a dative subject, the dative must originate in the matrix clause, as a dependent of kell. This modal assigns to its dative argument the role of obligation holder. For this role, animate Palinak in (43b) is game; but a fénymásolóknak in (44) is rejected because photocopiers cannot plausibly be interpreted as obligation holders.

(i) a fénymásolóknak el kell túnniük

the copiers.DAT dis- need appear.INF.3PL

'the copiers need to disappear'

16 "Preverb climbing" (recall footnote 14) becomes impossible when there is no coreference relation between the matrix obligation holder and the subject of the embedded clause: *Palinak el kell, hogy menjél is ungrammatical. 
In the construction illustrated in (43a), on the other hand, the nominative in the kell-clause MUST be coreferent with the subject of the embedded hogy-clause: ${ }^{17}$

(46) *PALI kell, hogy elmenjél

*Pali nem kell, hogy elmenjél

Pali needs that PV.go.SBJ.2SG

Pali not needs that PV.go.SBJ.2SG

This coreference requirement makes the construction in (43a) behave very much like the Brazilian Portuguese hyperraising construction in (1), and the English copy raising case in (2). Here, too, the two clauses must have coreferent subjects.

\subsubsection{NPI-licensing}

The parallel with Brazilian Portuguese hyperraising constructions goes further than this. Recall from section 3.1 that Nunes (2008) observes for Brazilian Portuguese that a strict NPI in the embedded clause of the hyperraising construction can be licensed by the negative subject of the matrix clause, as in (7), repeated here:

(7) ninguém parecia que ia mexer um dedo para me ajudar nobody seemed that went move a finger for me help

'nobody seemed like they were going to lift a finger to help me'

For Hungarian kell constructions, this pattern is reproduced in (47):

(47) senki nem kell, hogy a kisujját

*(is) megmozdítsa,

nobody not need that the little.finger.poss.acc IS PV.move.SBJ.3SG

hogy segítsen engem

that help.SBJ.3sG me

'nobody needs to lift a finger to help me'

The negative polarity item a kisujját sem mozdítja meg 'lift a finger (lit., move his little finger)' is a very strict NPI in ordinarily requiring a clausemate negation to license it: (48) (cf. Brazilian Portuguese (8)) is much degraded compared to (47).

$(48)$ ?'senki nem mondta, hogy a kisujját $\quad *$ (is) megmozdította

nobody not said that the little.finger.POSS.ACC IS PV.move.PST.3SG

17 Because "preverb climbing" is independently impossible in the absence of coreference (footnote 16), in the non-negative version of (46) the nominative is focused in an attempt to satisfy kell's stress-avoiding nature. But even with focus on Pali, the sentence fails. 
For Brazilian Portuguese long-distance licensing of strict NPIs in hyperraising constructions, we had discovered in section 3.1 that it works only if the licensing negation is harboured by the subject of predication: replacing ninguém 'nobody' with a non-negative subject and inserting the negation particle não 'not' in the matrix clause, as in (9), makes (7) ungrammatical.

(9) ${ }^{2} *_{\mathrm{O}}$ João não parecia que ia mexer um dedo para me ajudar João not seemed that went move a finger for me help

At this microscopic level, too, we find a parallel between the hyperraising construction of Brazilian Portuguese and Hungarian kell constructions: there are speakers for whom (49) is severely degraded compared to (47). ${ }^{18}$

(49) \%ános nem kell, hogy a kisujját is megmozdítsa
János not need that the little.finger.POss.ACC IS PV.move.SBJ.3SG

In the discussion in section 3.1, we discovered that both the movement account of hyperraising constructions and the predicational approach advocated in this paper can account for the NPI-licensing facts found in Brazilian Portuguese. On the predicational analysis, the NPI in (7) is licensed thanks to being included in the predicate created by the bound variable dependency in (3). Only examples in which the intended matrix licenser of the NPI in the embedded clause is the subject of predication for the complex predicate are predicted to be grammatical. On the movement approach, the difference between (7) and (9) falls out from the assumption that ninguém starts out in the subordinate clause, in a position local to mexer um dedo, and licenses the NPI prior to raising.

18 The judgements on (49) are not uniform, however: there are also speakers for whom this sentence is not (significantly) worse than (47). The problem here is probably rooted in part in the fact that strings of the type in (49) are analysable without an appeal to hyperraising/predication: in (49) János can be the undergoer of longdistance topicalisation ( $\overline{\mathrm{A}}$-movement) out of the lower clause. For the sentences in (47) and (48), which feature a negative quantifier in a negative concord dependency in the matrix clause, no such derivation is available. Ideally, to check the existence of a contrast between (47) and cases in which the intended licenser of the strict NPI downstairs is not the subject of the matrix clause, one would want to have recourse to sentences in which the non-negative matrix nominative is unambiguously the structural subject of the clause, and not eligible for treatment as a topic. Constructing such examples is severely hampered by the fact that the matrix clause needs to be negative and by the fact that it is very difficult to place the subject in clause-internal position in hyperraising constructions with negated kell (see footnote 11, (ii)). I have been unable to come up with optimal examples of hyperraising in sentential negation contexts. 
The Hungarian data are particularly interesting here because the movement analysis cannot be extended to Hungarian kell constructions. We will see why in the next subsection.

\subsubsection{The case against a movement derivation}

It cannot be that senki in (47) moves out of the embedded clause: the morphosyntactic properties of the lower clause are incompatible with senki originating there. To see this, consider the pairs of sentences in (50) and (51) (of which (51b) is identical with the relevant portion of (47)). In (50) and (51) we see striking differences between the hyperraising constructions in the b-sentences and their counterparts in the a-examples in which senki is inside the lower clause.

(50) a. az kell, hogy senki ne/se menjen el

it need that nobody not/nor go.SBJ.3SG PV

'it is necessary that nobody leave'

kell $\gg \operatorname{senki}$

b. senki nem/sem kell, hogy elmenjen

nobody not/nor need that PV.go.SBJ.3SG

'nobody needs to leave'

senki $\gg k e l l$

(51) a. az kell, hogy senki ne mozdítsa meg a kisujját sem it need that nobody not move.SBJ.3SG PV the little.finger.POSS.ACC SEM

'it is necessary that nobody lift a finger" $\quad k e l l \gg s e n k i$

b. senki nem kell, hogy a kisujját is megmozdítsa

nobody not need that the little.finger.POSS.ACC IS PV.move.SBJ.3SG

'nobody need(s to) lift a finger'

senki $\gg$ kell

The first and most eye-catching difference is that (a) the embedded clauses in the a-examples include, besides senki, also a sentential negation particle $(n e)$; but in the b-sentences, ne is absent from the subordinate clause. Related to the distribution of the sentential negation particle ne is the fact that (b) the word order in the subordinate clause is different in the a-and b-sentences: in the a-sentences the preverb (el, meg) must appear to the right of the subjunctival verb, whereas in the b-sentences it appears in front of it. Finally, an important morphological detail about (51) is that (c) the negative particle sem seen in (51a), which forms a constituent with a kisujját 'his little finger.ACC', is replaced in (51b) with its non-negative counterpart is $(\mathrm{sem}=i s+n e m$, where $n e m$ is the negation particle).

These morphosyntactic differences, taken together, militate rather strongly against the idea that senki in the b-sentences starts out in the 
embedded clause and raises up into the matrix clause: on such an analysis, one would have expected the embedded clause to behave in every way like a negative clause of the type seen in the a-sentences, quod non. The scope facts in (50)-(51) also give credence to the idea that senki in the b-sentences originates in the matrix.

\subsubsection{The predicational analysis for hyperraising constructions with kell}

On the alternative approach to hyperraising constructions advocated in this paper, the nominative, when it serves as the structural subject of the matrix clause, originates in that clause, and is introduced there as the subject of a complex predicate formed thanks to the fact that the matrix subject binds a silent pronoun in the lower clause as a bound variable. For the particular case of kell constructions, the analysis I would like to defend is represented in (52):

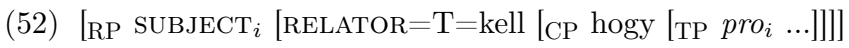

It is easy to show that the silent subject of the subordinate clause in hyperraising constructions with kell in Hungarian is indeed necessarily a bound variable. In a coordination case such as (53), the ellipsis can only be resolved in such a way that the subject of the hogy-clause is coreferent with te - a case of obligatory sloppy identity typical of bound variable readings. It is this bound variable that turns the lower clause into a predicate for the subject of RP.

(53) $\mathrm{Pali}_{i}$ el kell, hogy pro $_{i}$ menjen és te $\mathrm{e}_{k}$ is el kell hogy prok menjét

Pali PV need that go.SBJ.3SG and you also

\subsubsection{The modal is base-generated in $\mathrm{T}$}

For the Hungarian kell construction, I assume that kell is a lexicalisation of the RELATOR head. This is not because this modal only has finite forms: unlike the English modals, kell has non-finite forms, as in (54). But importantly, in the hyperraising construction, kell does always have to be finite: (55) is not possible with nominative senki (while it is fine with dative senkinek).

(54) Pali nem fog kelleni senkinek

Pali not will need.INF nobody.DAT

'nobody will need Pali' 
(55) senki*(nek) nem fog kelleni, hogy elmenjen nobody(DAT) not will need.INF that PV.go.SBJ.3SG

'nobody will need to go away'

This can be accounted for directly if kell is base-inserted in $\mathrm{T}$ in the hyperraising construction. ${ }^{19}$

An observation made by É. Kiss $(2009,223)$ that arguably ties in with the idea that kell in the hyperraising construction is directly inserted under $\mathrm{T}$ is that kell tends not to be separated from the hogy-clause by adverbial material:

(56) a. kellene nagyon, hogy elolvassa János a könyvet

would.need very.much that PV.read.SBJ.3SG János the book.ACC

b. *János el kellene nagyon, hogy olvassa a könyvet

János PV would.need very.much that read.SBJ.3SG the book.ACC

The degree modifier nagyon 'very (much)' can in principle combine perfectly well with kell, as shown in (56a); but in the hyperraising construction, nagyon cannot squeeze itself in between the modal and the subordinate clause, as the ungrammaticality of (56b) illustrates. ${ }^{20}$

19 This is not compromised by the fact that kell can co-occur with the irrealis marker volna in counterfactuals such as (i). As I argue in Den Dikken (2016), volna is the higher of the two elements in kellett volna, despite the fact that kellett apparently inflects for tense (it is arguably a participial form).

(i) én el kellett volna, hogy menjek

I PV need.PST would that go.1SG.SBJ

'I should have gone away'

${ }^{20}$ É. Kiss (2009) takes (56b) to show that in the construction at hand, kell and hogy form a head-level constituent: [V V C]. It seems unlikely that the idea that kell and hogy form a complex verb can be defended, especially in light of the fact that there does not appear to be an absolute ban on material between kell and hogy in the construction under discussion. Thus, we had already seen in (30), above, that kell and hogy can be separated by the nominative subject in focus fronting cases, and in the attested examples in (i) (which are perhaps worth one question mark, like (30)) we see that such separation is also possible in negative concord constructions. From the perspective of the text analysis, (30) and (i) indicate that $\mathrm{T}$ can be separated from the hogy-clause by raising to For or Neg.

(i) a. nem kell senki, hogy szeressen

'nobody needs to love me'

b. nem kell senki, hogy ott legyen

'nobody needs to be there'

c. nem kell senki, hogy egyetértsen velem 'nobody needs to agree with me'

Also, although nagyon does indeed resist interpolation between kell and hogy, the temporal modifier majd 'then' can fairly easily be positioned between kell and 


\subsubsection{Agreement}

In section 5.1.3, I highlighted a salient property of the Hungarian hyperraising construction with kell that needs to be accounted for: the fact that kell in (38) (repeated here) does not and cannot agree in $\varphi$-features with its nominative subject.

(38) 'AZÉRT kell/*kellenek a fénymásolók, hogy eltúnjenek therefore needs/need.3PL the copiers.PL(NOM) that disappear.SBJ.3PL

'therefore the photocopiers need to disappear'

This is not because kell simply lacks a person/number paradigm: in fact, it has a complete paradigm of person and number inflections:

the hogy-clause: the examples in (ii) are attested cases of this sort, taken from the internet (and judged as grammatical by the native speakers that I ran these sentences by).

(ii) a. a baleset résztvevôi a helyszínen meg kell majd,

he accident parties the scene.at PV need then

hogy nevezzék a biztosítójukat

that name.3PL.SBJ their insurance.ACC

'at the scene, the parties involved in an accident then have to name their insurance'

(ii) b. saját számításunk szerint a nagy biztosítók húzótermékeik own calculation.1PL according.to the large insurers products.POSSPL.3PL

77 százalékát le kell majd, hogy cseréljék 2017 januárjáig

77 percent.POSS.ACC PV need soon that adjust.3PL.SBJ 2017 January.TERM 'according to our own calculations, the large insurers then need to adjust 77 percent of their products before January 2017'

For majd, it is plausible to assume that it can be adjoined to TP. Assuming that the sentence-initial nominative noun phrases in (ii) are topicalised into an $\bar{A}$-position in the left periphery, and kell may make its way from $\mathrm{T}$ to a functional head position between $\mathrm{T}$ and the topic, we can derive the word order pattern illustrated in (ii). Degree modifiers such as nagyon 'very much' do not have the liberty to adjoin as high as TP. Since the structure in (52) does not give them an opportunity to adjoin anywhere between $\mathrm{T}$ and the hogy-clause either, (56b) is ungrammatical.

While it does often seem difficult to sever kell from hogy in the hyperraising construction, it would be too strong to rule such severing out altogether. Since É. Kiss' $(2009,224)$ suggestion has the direct effect of making kell and hogy strictly adjacent, I will set aside this possibility (which is not very plausible from a phrase-structural point of view in the first place). 
(57)
1SG kellek én kellek neked
'you need me'
2SG kellesz te kellesz nekem
'I need you'
3SG kell ő kell nekem
'I need him/her'
1PL kellünk mi kellünk nektek
'you.PL need us'
2PL kelletek ti kelletek nekünk
'we need you.PL'
3PL kellenek ők kellenek nekünk
'we need them'

So sentences of the type in (38) with $\varphi$-inflection on kell are a priori perfectly imaginable. But (38) is ungrammatical with number-inflected kellenek, and similarly, (58) is impossible with person-inflected kellek. As a matter of fact, we might even expect kell to inflect not just for the person and number of its nominative subject but to also engage in a definiteness agreement relation with the hogy-clause, as in (59), with kellem: after all, hogy-clauses in complement positions to verbs ordinarily control the definite conjugation of those verbs, as shown in (60). But we do not see kellem either: (59) is impossible. ${ }^{21}$ These facts call for a syntactic explanation.

(58) én el kell/*kellek, hogy menjek

I PV need.3SG/need.1SG.INDEF that go.SBJ.1SG

'I need to go away'

(59)*én el kellem, hogy menjek

I PV need.1SG.DEF that go.SBJ.1SG

(60) én akarom/*akarok, hogy elmenjél

I want.1SG.DEF $/{ }^{*}$ INDEF that PV.go.SBJ.2SG

'I want you to go away'

${ }^{21}$ In Western Hungarian dialects spoken in areas where German is spoken as well, a 'personal kell' has emerged, with full person and number inflections and a definiteness distinction, found in constructions in which kell takes an uninflected infinitival complement (ungrammatical in standard Hungarian), as in (i); see É. Kiss (2009). (In the dialects in question, the vowel of kell is centralised, which the orthography reflects as köll.)

(i) a. én el köllök menni

én el köllöm érni a vonatot

b. te el köllösz menni

te el köllöd érni a vonatot

c. ő el köll menni

ő el kölli érni a vonatot

d. mi el köllünk menni

mi el kölljük érni a vonatot

e. ti el köllötök menni

ti el köllitek érni a vonatot

f. oók el köllenek menni

ôk el köllik érni a vonatot

'I/you/(s)he/we/they

'I/you/(s)he/we/they

need to go away'

need to catch the train' 
Objective or definite agreement arises in Hungarian only in constructions in which a verb (a) has a definite noun phrase or a hogy-clause in its complement and (b) is engaged in a person and number agreement relationship with the nominative subject. The so-called tárgyas ragozás 'objective conjugation' is a subject-agreement paradigm which, in addition to reflecting the person and number of the subject, also signals the fact that there is a definite DP or finite clause in the verb's complement. In the hyperraising construction under discussion, kell does not engage in a person/number agreement relation with the nominative subject - for reasons that I will turn to shortly. Because it does not and because agreement with the subject is a prerequisite for the objective conjugation, kell in hyperraising constructions can only be inflected according to the paradigm of the subjective/indefinite conjugation. Provided, therefore, that we can ensure that kell does not agree with the nominative subject for person and number, we can straightforwardly derive the invariant 3SG.INDEF form of kell. ${ }^{22}$

The key question now is how kell can be prevented from establishing a person/number agreement relation with its nominative subject in hyperraising constructions. To understand this, we need to go back to the structure in (52), repeated below, and discuss its properties in more detail.

(52) $\left[{ }_{\text {RP SUBJECT }} i\left[\right.\right.$ RELATOR $=\mathrm{T}=$ kell $\left[\mathrm{CP}\right.$ hogy $\left.\left.\left.\left[\mathrm{TP} \mathrm{pro}_{i} \ldots\right]\right]\right]\right]$

22 This will also account for the fact that kell cannot engage in a definiteness agreement relation with the object of the embedded clause - not even when this object is physically placed in the kell clause, as in (i).

(i) én ezt meg kell(*em), hogy magyarázzam?

I this.ACC PV need(1SG.DEF) that explain.1SG.SBJ

'do I need to explain this?'

It is well known that Hungarian under certain circumstances (and subject to speaker variation) allows a matrix verb to entertain a definiteness agreement relation with an accusative case-marked noun phrase semantically belonging to its finite subordinate clause: in (ii), akarsz bears indefinite inflection thanks to the fact that it agrees with mit, the accusative object of the lower verb.

(ii) mit akarsz, hogy megmagyarázzak?

what.ACC want.2SG.INDEF that PV.explain.SBJ.1SG.INDEF

'what do you want me to explain?'

But in the "hyperraising" construction with kell, the matrix verb cannot agree in definiteness with the lower object, not even when it finds itself in the kell clause: (i) is ungrammatical with kellem because in order for a verb to agree in definiteness with an object, it must agree in $\varphi$-features with the nominative subject, which kell does not do in this construction. 
As I mentioned previously, this structure treats kell as the RELATOR of the predicate (the $\mathrm{CP}$ containing the bound variable pronoun) and its subject. With kell base-generated in $\mathrm{T}$ (recall section 5.3.5), this subject is base-merged in SpecTP. Since the subject is merged directly in SpecTP, it cannot engage in an Agree relation with $\mathrm{T}$ for its $\varphi$-features in Hungarian. There are two ways of deriving this from the theory. One is to say that Hungarian sets the directionality of Agree (which may be parametrised for individual languages) to 'strictly downwards': then T cannot establish an Agree relation with anything that is base-merged in SpecTP; subjects can only agree in $\varphi$-features with the finite verb if they originate in the c-command domain of $\mathrm{T}$, where they can serve as goals for $\mathrm{T}$ under Downward Agree. Alternatively, $\varphi$-agreement involves the $\mathrm{C}-\mathrm{T}$ complex (in line with Chomsky 2008; 2013), and the C-T system can Agree with something in SpecTP only if C and T can co-project (in the sense of Den Dikken 2017). Hungarian arguably answers 'no' to the question of whether $\mathrm{T}$ can coproject with C: thus, the language has no 'complementiser-trace effects', which Den Dikken (2017) analyses in terms of C-T co-projection. Assuming that Hungarian $\mathrm{T}$ cannot co-project with $\mathrm{C}$, we derive the fact that when a subject is base-merged in SpecTP, the finite verb cannot agree with it in Hungarian. Whichever approach we adopt, it follows that subjects in Hungarian can $\varphi$-agree with the finite verb only if they are merged lower than SpecTP. What makes the subject of hyperraising constructions with kell special is precisely the fact that the subject is base-generated directly in SpecTP (as in (52)), in a position in which it is prevented from agreeing in $\varphi$-features with kell. ${ }^{23}$

In the English copy raising and Brazilian Portuguese hyperraising constructions, the nominative subject of the matrix seem-type verb clearly does engage in a $\varphi$-agreement relationship with that verb. Let me repeat

${ }^{23}$ An immediate consequence of the approach to the Hungarian agreement facts is that nominative case must either be a non-assigned (default) case in Hungarian or else be assigned under a mechanism that is different from Agree (for instance, the Spec-Head relation). After all, the subject of the hyperraising construction with kell is base-merged in SpecTP, where, as I just argued, it cannot serve as an Agreegoal for $\mathrm{C}-\mathrm{T}$ in Hungarian. The idea that nominative case is the default case of Hungarian is entirely defensible; but it may also be that we are dealing with an assigned, structural case after all, and that case avails itself of a different mechanism from the one exploited by $\varphi$-agreement. The latter would mean that structural case and $\varphi$-agreement need to be divorced - contrary to the line of research that has dominated the minimalist research programme since Chomsky (1995), where $\varphi$ and case were inextricably linked. For our purposes in this paper, no decision on the matter is urgently needed; so I will leave this interesting matter for another occasion. 
the examples in (1) and (2) at this point, and juxtapose them to their counterparts with first person singular subjects, to bring this $\varphi$-feature agreement out clearly. ${ }^{24}$

(61) a. ${ }^{\%}$ eu pareço que 'tou doente

I seem.1SG that be.1sG sick

'I seem to be sick'

b. o João parece que 'ta doente the João seem.3SG that be.3sG sick

'João seems to be sick'

(62) a. I seem like I'm sick

b. John seems like he's sick

The form of the raising verb in (61) and (62) covaries with the person (and number) specification of its subject. This is a clear case of agreement.

The active ingredient of the analysis of the Hungarian (lack of) $\varphi$-agreement facts is the hypothesis (independently supported on the basis of the data discussed in section 5.3.5) that the modal kell in hyperraising constructions is base-generated in T. For the semi-copula in the English copy raising construction, on the other hand, it is clear that it is merged with the small clause in which the predication relation between the subject and the CP is established - a small clause headed by a RELATOR from the set $\{$ like, as, out, $\emptyset\}$. In (6), repeated below, the subject of the matrix clause is merged as the specifier of the small clause in the complement of the semi-copula, and eventually raises into the structural subject of the clause. In its position of first merge, the subject of the matrix clause is certainly in the Agree domain for the $\mathrm{C}-\mathrm{T}$ probe. So $\varphi$-feature agreement between seem/turn and the matrix subject is straightforwardly guaranteed. ${ }^{25}$

(6) $\left[\right.$ seem/turn $\left[\mathrm{RP} \mathrm{he}_{i}\left[\mathrm{RELATOR}=\{\right.\right.$ like, as, out, $\emptyset\}\left[\mathrm{CP}\right.$ (if/though) he ${ }_{i}$ is sick] $\left.\left.]\right]\right]$

${ }^{24}$ Nunes $(2008,101)$ points out that there are speakers who do not find $(61 \mathrm{a})$ acceptable, whence the "\%".

${ }^{25}$ An interesting question that arises with regard to the copy raising construction is whether it allows the subject of the matrix clause to stay in the subject position of the small clause in (6). For the garden-variety raising construction featuring a to-infinitive below seem, we know that the there-expletive construction is licit: (ia). But (ib) is ungrammatical. Given that in (6) the complement of seem is a small clause, just as in (ib), we expect (6) to behave like (ib) in the there-expletive construction. This is correct: while (iia) is fine, (iib) is impossible.

(i) a. there seems to be someone sick (ii) a. someone seems like he's sick b. *there seems someone sick

b. *there seems someone like he's sick 
For English, the presence in the typical copy raising construction of an element like like or as that can be mapped into the RELATOR position of the small clause explicitly signals the base-generation of the subject below seem. For Brazilian Portuguese there is no comparable functional element that will guarantee this. But there are no indications to the learner that parecer 'seem' is anything other than an ordinary verb. The learner will assume as the null hypothesis, therefore, that it is a regular verbal root, and that the predication structure involving the subject and the finite CP is established in parecer's complement, as in English (6).

\subsubsection{No hyperraising with inflected infinitives}

In section 4.4, we saw that although Brazilian Portuguese allows inflected infinitival clauses in the complement of some of the main-clause predicate heads that are featured in hyperraising constructions, it does not allow hyperraising from an inflected infinitive: recall (24). For Hungarian, a similar ban on hyperraising from an inflected infinitive can be observed, as shown in $(63) .{ }^{26}$

(24) a. è bem provável [os professores terem elogiado o diretor] is very probable the professors have.INF.3PL praised the director 'it is very likely for the professors to have praised the director'

b. *os professores são bem prováveis[terem elogiado o diretor] the professors are very probable have.INF.3PL praised the director intended: 'the professors are very likely to have praised the director'

(65) a. nekem el kell mennem

DAT.1SG PV need go.INF.1SG

'I need to go away'

b. *én el kell mennem

I PV need go.INF.1SG

intended: 'I need to go away'

In section 4.4, I hypothesised that the ungrammaticality of the b-sentences follows from the limited size of the inflected infinitive in the structure of

${ }^{26}$ Simonyi $(1889,8)$ says that in Transylvania (more particularly, in the hétfalusi csángó variety) one finds (alongside nekem el kell mennem 'DAT.1SG away needs go.INF.1SG' and én el kell (hogy) menjek 'I away needs (that) go.SBJ.1SG') sentences such as én el kell mennem a templomba 'I away needs go.INF.1SG the church.to' and én kellett minden adósságot megfizetnem 'I needed every debt.ACC off.pay.INF.1SG'. So in csángó varieties (63b) does appear to occur (though more research on this is necessary). But in the standard language, it is robustly deviant. 
hyperraising constructions: they are IPs, not CPs; consequently, the bound variable pronoun needed inside the inflected infinitive in these hyperraising constructions will be bound within its local domain, in violation of Principle B of the Binding Theory. For Hungarian, the presumption that we are dealing with a structure no larger than IP receives support from the fact that the inflected infinitive in (63a) does not accommodate positions in the clausal left periphery for fronted topics or foci. ${ }^{27}$

\subsection{Hyperraising in Hungarian: some conclusions}

In the discussion in this section, we have come across a number of striking parallels between bona fide hyperraising and copy raising constructions and Hungarian sentences with a matrix clause featuring the modal kell or an adjective such as biztos 'certain' or valószinü 'likely' and a nominative subject that 'belongs to' the finite subordinate clause. Though sentences of this type in which the nominative appears in initial position are often best analysed as cases of long-distance topicalisation ( $\overline{\mathrm{A}}$-movement out of the lower clause into the left periphery of the matrix clause), we have found grounds for thinking that under particular circumstances the nominative functions as the structural subject of the matrix clause-and is base-generated in that clause. The argument for a base-generation analysis of hyperraising constructions (i.e., one in which the subject originates

27 Thanks to Kriszta Szécsényi for pointing this out to me. In this respect, the inflected infinitive in (63a) differs from inflected infinitives in many other contexts in Hungarian. It is important to bear in mind that the hypothesis that the inflected infinitive in (63a) is smaller than CP does not export to inflected infinitives in this language across the board.

A reviewer asks how (63a) (which exhibits the same coreference requirement as does its counterpart with a subjunctive clause: thus, ${ }^{*}$ nekem nem kell elmenned 'I.DAT not needs away.go.2SG, intended: I don't need you to leave' is ungrammatical; cf. (46), above) manages to escape a Principle B violation. As I pointed out in footnote 15 , the dative in (63a) is probably the subject of the infinitive (see Tóth 2000), not base-generated as a dependent of the matrix clause - so (63a) arguably is not a candidate for a hyperraising (i.e., predicational) derivation. With nekem in (63a) originating in the infinitival clause, no binding-theoretic issues arise. If the dative were to start out in the matrix clause, it would not be able to c-command (the subject of) the infinitival clause from an A-position; it could c-command the infinitive only from an $\bar{A}$-position in the matrix left periphery. So even with dative nekem originating in the matrix clause, no Principle B violation could arise in (63a): Principle B only constrains A-binding relations; no local A-binding configuration could arise in (63a). (The fact that (63a) does not allow disjoint reference does not as such follow from what I just said, and remains an open question.) 
in the matrix clause and gets the subordinate $\mathrm{CP}$ as its predicate) is especially strong for Hungarian sentences featuring a negative quantifier as the matrix subject (recall section 5.3.3). Hungarian hyperraising constructions with the modal kell introduced a special twist in the realm of $\varphi$-feature agreement. The fact that kell (despite possessing a full $\varphi$-paradigm) cannot agree in number or person with the nominative subject of hyperraising constructions was explained in section 5.3 .5 with an appeal to the hypothesis (for which independent support was provided in section 5.3.4) that the modal kell in these constructions is base-inserted in T, very much like the modals of English.

\subsection{Postlude: some complications in the syntax of kell constructions with "clause union"}

In the examples so far discussed in section 5, the constituent "shared" by the two clauses consistently is the notional subject of the embedded clause, and surfaces with nominative case when the matrix predication is finite, and with accusative case in ECM constructions embedded under tart 'take, consider' (recall section 5.1.3 for examples of the latter type). But as a reviewer of the previous version of this paper points out, the "shared" constituent in kell + subjunctive constructions seems to be able to have a wide variety of grammatical functions and cases:

(66) a. a fénymásolót el kell, hogy adjuk

the copier.ACC PV needs that sell.SBJ.1PL

'we need to sell the photocopier'

b. a fénymásolóban meg kell, hogy bízzunk

the copier.INESS PV needs that trust.SBJ.1PL

'we need to trust the photocopier'

c. a fénymásolótól nem kell, hogy féljetek

the copier.ELAT not needs that fear.SBJ.2PL

'you need not be afraid of the photocopier'

Examples such as the ones in (64) are straightforwardly analysable along the lines of our initial examples in (28), repeated below, as cases of longdistance topicalisation into the left periphery of an impersonal matrix clause (cf. English the photocopier, it is necessary that we sell), as the reviewer is correct to point out. 
(28) a. a fénymásoló el kell, hogy tûnjön the copier(NOM) dis- needs that appear.SBJ.3SG 'the photocopier needs to disappear'

b. a fénymásoló ki kell, hogy kapcsolva legyen the copier(NOM) off needs that switched be.SBJ.3SG 'the photocopier needs to be switched off'

As such, the sentences in (64) do not bear in any direct way on the analysis of hyperraising and copy raising constructions, the central theme of this paper. But interestingly, a subset of the examples in (64) can be turned into sentences that look very much like the cases in (30), repeated below, for which I had argued above that they instantiate hyperraising. Thus, consider the versions of (64) given in (65). ${ }^{28}$

(30) a. ?AZÉRT kell a fénymásoló, hogy eltûnjön, mert... therefore needs the copier(NOM) that disappear.SBJ.3SG because 'the photocopier needs to disappear because...'

b. ?AZÉRT kell a fénymásoló, hogy kikapcsolva legyen, mert... therefore needs the copier(NOM) that off.switched be.SBJ.3SG because 'the photocopier need to be switched off because...'

(65) a. ?"AZÉRT kell a fénymásolót, hogy eladjuk, mert... therefore needs the copier.ACC that PV.sell.SBJ.1PL because 'we need to sell the photocopier because...'

b. ?AZÉRT kell a fénymásolóban, hogy megbízzunk, mert... therefore needs the copier.INESS that PV.trust.SBJ.1PL because 'we need to trust the photocopier because...'

c. *AZÉRT kell a fénymásolótól, hogy féljetek, mert... therefore needs the copier.ELAT that fear.SBJ.2PL because 'you need to be afraid of the photocopier because...'

Relevant here as well are negative concord sentences of the type in (66) (two attested examples found on the internet, and run by native-speaker

${ }^{28}$ Potentially interesting (though it remains obscure to me how it can be understood) is the contrast between definite and indefinite accusative objects seen in ? AZÉRT kell a fénymásolót, hogy megvegyük 'that's why we need to buy the copier' and *AZÉRT kell egy új fénymásolót, hogy vegyünk 'that's why we need to buy a new copier'. No such contrast arises when the accusative is placed in initial position in the matrix clause (and arguably occupies a topic position in the $\overline{\mathrm{A}}$ left periphery): the relevant variants of both examples just given are perfectly acceptable. 
linguists, whose judgements are reported here), with the negative constituent inserted between kell and the hogy-clause and interpreted as a dependent of the embedded clause. Here again, judgements seem highly variable.

(66) a. ?nekem nem kell semmivel hogy meglepjenek

I.DAT not needs nothing.with that PV.surprise.SBJ.3PL

'they needn't surprise me with anything'

b. ? ez nem kell senkit, hogy befolyásoljon

this not needs nobody.ACC that PV.influence.SBJ.3SG

'this needn't influence anyone'

What might be going on in these kinds of sentences?

It seems to me likely that there exists a link between these Hungarian examples and Dutch sentences of the type in (67) (see Barbiers 2002 for what I believe is the first mention - at least in the theoretical literature - of cases similar to $(67 \mathrm{a})):^{29}$

(67) a. (?)? ik denk met een mes dat de moord gepleegd is

I think with a knife that the murder committed is

'I think that the murder has been committed with a knife'

b. (?)? ik denk op de regering dat je moet kunnen vertrouwen

I think on the government that you must be.able trust

'I think that you must be able to have faith in the government'

c. $\quad *_{\mathrm{ik}}$ denk de regering dat je moet kunnen vertrouwen

I think the government that you must be.able trust

'I think that you must be able to trust the government'

d. *ik denk voor het extremisme dat je bang moet zijn

I think for the extremism that you afraid must be

'I think that you must be afraid of extremism'

${ }^{29}$ As a follow-up to footnote 28 , I point out here that to my ear, there is no definiteness effect for 'splicing' of direct objects in the Dutch cases. Thus, I find both *ik denk het kopieerapparaat dat we moeten kopen 'I think a copying machine that we should buy' and $* i k$ denk een nieuw kopieerapparaat dat we moeten kopen 'I think a new copying machine that we should buy' are both very poor. As a pair, they contrast with ${ }^{(?)} i k$ denk in een nieuw kopieerapparaat dat we moeten investeren 'I think in a new copying machine that we should invest' or (?)? $i k$ denk voor een nieuw kopieerapparaat dat we moeten gaan sparen 'I think for a new copying machine that we should go and save', with an in- or voor-PP in the matrix clause, which have the same status as $(67 \mathrm{a}, \mathrm{b})$ in the main text. 
These sentences, like the Hungarian cases in (65) and (66), receive variable judgements, and never seem perfectly good. ${ }^{30}$ More microscopically, Dutch (67) and Hungarian (65)-(66) seem to give rise to very similar (dis)preferences: in particular, direct objects are generally quite difficult to "splice" into the matrix clause; and the PP-dependent of predicates such as be afraid cannot be placed to the immediate left of the embedded complementiser at all (see (65c) and (67d)) - even though other PPs undergo this process fairly easily (see (65b), (66a) and (67a,b)).

It is not difficult to show for Dutch that sentences of the type in (67a,b) position the PP in the matrix clause, not in the SpecCP of the embedded clause. Thus, in (68) (featuring a periphrastic pluperfect) there can be no doubt that the $\mathrm{PP}$ is a constituent of the matrix:

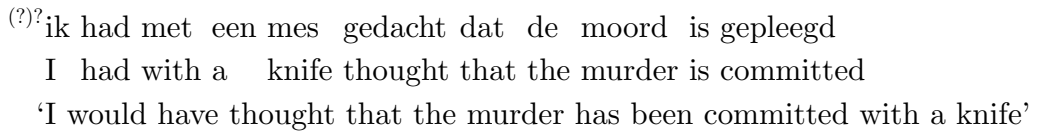

It is also fairly easy to be convinced that the PP met een mes in (67a) and (68) is base-generated in the higher clause, not moved into it from the lower one. 'Scrambling' is robustly clause-bound in Dutch, as is in fact confirmed by the ungrammaticality of (67c) and (68d).

There may be some sense to the idea that the constituents that can be "spliced" into the matrix clause in constructions of the type in (65)-(68) are in a predicational relationship with the subordinate clause. But if they are, then it must be the "spliced" PPs that are the predicates: it would be very awkward to treat, say, the instrumental PP in (66a) or $(67 a) /(68)$ as a subject of predication. The analysis proposed in section 2 for hyperraising constructions (reproduced below) does not automatically carry over to the "splicing" cases in (65)-(68), therefore.

(3) [RP $\operatorname{SUbJeCt}_{i}[$ Relator $[\mathrm{CP}$ C [TP PRONOUn $\left.\left.i \ldots]]\right]\right]$

But if the quintessence of hyperraising (and copy raising) is the existence of a predication relation in the matrix clause of which the 'shared' constituent and the subordinate $\mathrm{CP}$ are the main terms, the predicational approach does provide an opening for the analysis of the cases brought up in the present section. The central claim of Den Dikken (2006) is that predication relations in syntax are fundamentally asymmetrical (i.e., always mediated by a RELATOR that takes one of the terms as its complement and the other

${ }^{30}$ All of $(67 \mathrm{a}-\mathrm{d})$ become perfect with ellipis of the that-clause, as fragment answers to questions of the type 'what do you think the murder was committed with?'. 
as its specifier) but non-directional. It should in principle be possible in this theory to construe the constituent in the specifier position of the RELATOR phrase in the structure of hyperraising constructions as the predicate, with the complement-CP then coming to serve as the subject of predication:

$\left(3^{\prime}\right)$ [RP PREDicate [RELATOR [CP C [TP $\left.\left.\left.\ldots ..\right]\right]\right]$

For an analysis of the type in $\left(3^{\prime}\right)$ to be semantically plausible, the constituent in SpecRP will need to be interpretable as a predicate of the embedded proposition. For objects and lexically selected PPs, this is not the case, which may be responsible for the severely degraded status of the examples in (65a), (66b) and (67c) (with direct objects) and (65c) and (67d) (with selected PPs). How sensible it is to treat the PPs in (65b), (66a), (67a,b) and (68) as predicates of the embedded clause is a question that I do not have the means and space to address at this time (and which is, anyway, well beyond the scope of this paper).

It may be that $\left(3^{\prime}\right)$ is not on the right track as an approach to the grammatical cases of 'splicing' presented in this section, and that their syntax is ultimately not related to that of hyperraising constructions. But the fact that the predicational analysis of hyperraising in (3) at least opens up a possible perspective on these highly mysterious 'splicing' constructions could very well turn out to be a hidden bonus of the overall approach.

\section{Concluding remarks: movement or predication?}

In this paper, I have put forward an approach to hyperraising and copy raising constructions in which the embedded clause out of which the matrix subject seems to have moved is actually a predicate of this subject, which is base-generated in the matrix clause. For its simplicity, the predicational analysis should qualify as the null hypothesis. The fact that it accommodates the key properties of hyperraising and copy raising constructions efficaciously suggests that there are no empirical impediments to the adoption of the predicational approach.

The burden of proof is now squarely on the shoulders of those who would like to uphold a movement analysis. Any argument for movement being involved in the English copy raising construction is severely impaired by the grammaticality of examples of the type illustrated in (69) (taken from the internet, and checked with native speakers for acceptability; recall also (21b) and (22b)). As these sentences show, the copy pronoun can be located inside the subject of the lower clause: it does not have to be the 
subject of the lower clause itself. Asudeh and Toivonen (2012) note that there are even speakers of English for whom the copy pronoun does not need to be (inside) the subject of the lower clause: it can even be an object, as in $(70):{ }^{31}$

(69) a. he seems like his mind is somewhere else/made up

b. he seems like his character is working against him

c. he seems like his vision is impaired

(70) a. he seems like she terrifies him

b. he seems like she's lucky to have him

c. he seems like she's everything to him

On no reasonable assumptions about raising (or movement more generally) could one uphold an analysis of the examples in (69) and (70) in which the subject of the matrix clause arrives in SpecIP through movement out of the lower clause, out of or across its subject. Copy raising constructions of the type in (69) and (70) plainly do not involve raising. To the examples in (69) and (70), the predicational approach applies unproblematically, with the pronoun in the lower clause serving as a bound variable and turning the containing clause into a predicate for the matrix subject.

Brazilian Portuguese and Hungarian do not seem to be as generous as English in the location of the bound variable pronoun - which is silent in these languages. This, I submit, has much more to do with the distribution of pro (the silent pronominal variable) than with the syntax of predication as such. As English (69) and (70) show, the bound variable pronoun can in principle be located anywhere inside the clause embedded under the matrix verb. But licensing pro anywhere other than in the subject position of a finite clause is often very difficult.

It would be interesting to look for cases in which non-subject pro-drop should be allowed in principle, to see if those could reproduce the liberal pattern exhibited by English copy raising. This remains on the research agenda.

${ }^{31}$ Recall footnote 2, above. The examples in (70) are again attested examples taken from the web, and checked for grammaticality. 


\section{Acknowledgements}

The research done for this paper was financially supported by Hungarian Scientific Research Fund (OTKA) grant nr. 84217, to Balázs Surányi, which is very gratefully acknowledged. I would like to thank Katalin É. Kiss for inviting me to contribute a paper to the new Acta Linguistica Academica, and to congratulate her and her co-editors on the happy occasion of the rechristening of this journal. I would also like to prominently acknowledge the incisive criticism of an earlier version of this piece supplied by two anonymous reviewers. For their help with some of the Brazilian Portuguese material presented in this paper, I am greatly indebted to Karen Duek, Jairo Nunes and Marcelo Sibaldo. For extensive discussion of the Hungarian sentences included in section 5, and for meticulously reading and commenting on earlier drafts of the paper as a whole, I am deeply grateful to Éva Dékány and Kriszta Szécsényi. For the things in this paper that may turn out to be good, the aforementioned people deserve a large slice of the credit; for everything that will prove to be wrong, I alone am responsible.

\section{References}

Asudeh, Ash and Ida Toivonen. 2012. Copy raising and perception. Natural Language and Linguistic Theory 30. 321-380.

Barbiers, Sjef. 2002. Remnant stranding and the theory of movement. In A. Alexiadou, E. Anagnostopoulou, S. Barbiers and H.-M. Gärtner (eds.) Dimensions of movement: From features to remnants. Amsterdam \& Philadelphia: John Benjamins. 47-67.

Boeckx, Cedric, Norbert Hornstein and Jairo Nunes. 2010. Control as movement. Cambridge: Cambridge University Press.

Chomsky, Noam. 2008. On phases. In R. Freidin, C. P. Otero and M. L. Zubizarreta (eds.) Foundational issues in linguistic theory. Essays in honor of Jean-Roger Vergnaud. Cambridge, MA: MIT Press. 134-166.

Chomsky, Noam. 2013. Problems of projection. Lingua 130. 33-49.

Dikken, Marcel den. 2006. Relators and linkers: The syntax of predication, predicate inversion, and the copula. Cambridge, MA: MIT Press.

Dikken, Marcel den. 2016. Hungarian nominal and verbal inflection integrated: The role of clitics. Manuscript. ELTE/Hungarian Academy of Sciences.

Dikken, Marcel den. 2017. Dependency and directionality. Cambridge: Cambridge University Press.

É. Kiss, Katalin. 2009. Nekem el kell menni/el kell mennem/el kell, hogy menjek/el kell menjek/el kellek menni. In K. É. Kiss and A. Hegedûs (eds.) Nyelvelmélet és dialektológia [Linguistic theory and dialectology]. Piliscsaba: PPKE BTK, Elméleti Nyelvészeti Tanszék - Magyar Nyelvészeti Tanszék. 213-238.

Ferreira, Marcelo. 2000. Argumentos nulos em português brasileiro [Null arguments in Brazilian Portuguese]. MA Thesis. Universidade Estadual de Campinas.

Ferreira, Marcelo. 2004. Hyperraising and null subjects in Brazilian Portuguese. MIT Working Papers in Linguistics 47. 57-85.

Hoekstra, Teun and René Mulder. 1990. Unergatives as copular verbs: Locational and existential predication. The Linguistic Review 7. 1-79. 
Kayne, Richard S. 1975. French syntax: The transformational cycle. Cambridge, MA: MIT Press.

Koster, Jan. 1978. Why subject sentences don't exist. In J. S. Keyser (ed.) Recent transformational studies in European languages. Cambridge, MA: MIT Press. 53-64.

Martins, Ana Maria and Jairo Nunes. 2006. Apparent hyper-raising in Brazilian Portuguese: Agreement with topics across a finite CP. In P. Panagiotidis (ed.) The complementiser phrase: Subjects and wh-dependencies. Oxford: Oxford University Press. 143-163.

Moro, Andrea. 1997. The raising of predicates: Predicative noun phrases and the theory of clause structure. Cambridge: Cambridge University Press.

Nunes, Jairo. 2008. Inherent case as a licensing condition for A-movement: The case of hyper-raising constructions in Brazilian Portuguese. Journal of Portuguese Linguistics 7. 83-108.

Potsdam, Eric and Jeffrey Runner. 2001. Richard returns: Copy raising and its implications. In M. Andronis, C. Ball, H. Elston and S. Neuvel (eds.) CLS37: The main session, Vol. 1. Chicago: Chicago Linguistic Society. 453-468.

Simonyi, Zsigmond. 1889. Kombináló szóalkotás [Combining word formation]. Magyar Nyelvôr 18. 1-8.

Tóth, Ildikó. 2000. Inflected infinitives in Hungarian. Doctoral dissertation. Tilburg University.

Ura, Hiroyuki. 1998. Checking, economy, and copy-raising in Igbo. Linguistic Analysis 28. $67-88$.

Williams, Edwin. 1994. Thematic structure in syntax (Linguistic Inquiry Monograph 23). Cambridge, MA: MIT Press.

Williams, Edwin. 2006. The subject-predicate theory of there. Linguistic Inquiry 37. 648651. 